\title{
Hyperlink networks as a means of mobilization used by far-right movements
}

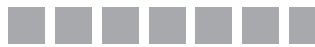 \\ Ina Fujdiak \\ ORCID: 0000-0002-0523-5795 \\ MASARYK UNIVERSITY, CZECH REPUBLIC \\ Petr Ocelík \\ ORCID: 0000-0002-0690-265X \\ MASARYK UNIVERSITY, CZECH REPUBLIC
}

DOI: 10.19195/1899-5101.12.2(23).2

\begin{abstract}
The article provides an analysis of the mobilization strategies of far-right movements from the Czech Republic and Germany based on the content they provide via hyperlinks on their websites. Vertical and reticular characteristics of the hyperlinked pages have been analyzed, two aspects which form central parts of the mobilization strategies of social movements. The vertical level refers to territorial relations, while the reticular level refers to relations with other actors. The analyses confirmed that the movements focused on the vertical level to their countries of origin. With respect to reticular characteristics the type of hyperlinked content neither differs significantly throughout countries, nor throughout segments of the far-right movement. Additionally, the analysis of the type of hyperlinked content provides insight into the general mobilization strategies employed.
\end{abstract}

KEYWORDS: online mobilization, far-right movements, social network analysis, Czech Republic, Germany, transnationalism.

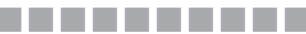

\section{INCREASED INFLUENCE OF POPULISM AND FAR-RIGHT MOVEMENTS}

With the arrival of over a million people coming from countries outside Europe in 2015, far-right and populist political parties and movements all over Europe, which already existed before, could increase their influence and importance. This caused authors to write about the rise of the support for far-right groups and political parties all over Europe (Aisch, Pearce, \& Rousseau, 2017; Greven, 2016). Recent events, for example the populist right party Alternative for Germany (AfD) gaining 12.6\% 
in the German federal elections in 2017 and by this becoming the third strongest party, confirm this trend (Bundeswahlleiter, 2017).

Many far-right groups oppose the European Union and other supranational institutions and argue in favor of strengthening nation states and their respective sovereignties. Populist movements and parties strongly emphasize the element of nationalism in their ideologies and transnational cooperation at least in the party sectors is not as strong. However, far-right movements and parties also cooperate with activists and movements from other countries (Caiani \& Kroel, 2014). The specific characteristics of this cooperation have led to a specific pattern of Europeanization of populist parties, which includes aspects such as political competition and negotiation. This pattern of Europeanization results in instability and fragmentation of the transnational party coordination (Gomez-Reino, 2018). Also, transnational cooperation of populist right parties is, according to Mudde, exclusively the result of domestic considerations (2007, cited in Gomez-Reino, 2018)

The internet and modern communication technologies recently account for 70$80 \%$ of the far-right's networking, hence are of key importance for the mobilization of supporters (Köhler, 2015; Polletta et al., 2013). The following article provides an analysis of the content and the nationalities of websites that are hyperlinked by far-right movements from the Czech Republic and Germany to research the mobilization strategies of far-right movements in cyberspace. The international and domestic connections of the selected social movement organizations (SMOs) as well as their relations with different types of actors are analyzed based on in- as well as outbound hyperlinks.

\section{FAR-RIGHT AND POPULIST MOVEMENTS}

The term "far right" has already been used in 2007 (Kopeček) and since then has been established as an umbrella term that includes radical as well as extreme right actors. The main difference between the terms radicalism and extremism is that radicals do accept basic characteristics of democracy, while extremists reject them. However, also radicals do not accept liberal democracy including pluralism and minority rights (Mudde, 2014; Backes \& Jesse, 1993; Bötticher \& Mares, 2012). Additionally, there is the concept of populism, which represents most of all a certain strategy or style of politics that differentiates between good, pure people and the corrupt elites (Mudde, 2015). Also, populism has been defined as anti-pluralist and based on the claim to be the sole representation of the people without any legitimate competitor for force. Additionally, citizens that do not support the populist group are considered to not belong to the real people (Müller, 2016). Further, the term has been described as a combination of expressive rhetoric, a demagogic way of speaking, folksy, content wise simplifying messages and a direct form of political leadership (Holtmann, Krappidel, \& Rehse, 2006, p. 32). In the context of the movements selected for the analyses, populist strategies are strongly used by Pegida and 
the Initiative against Islam in the Czech Republic and to a certain extent also by the youth groups of far-right parties, while the Identitarian movements hardly use any populist strategies.

While far-right and populist parties have already been researched extensively, scientific studies about the more informal and less institutionalized context of farright and populist movements are not found as often. In the 1960s and 1970s social movements were conceptualized as being exclusively oriented to the left, which is, however, no longer applicable today, where we can find a variety of different movements and mobilization contexts (Klandermans, 2013). Tarrow defined social movements as "collective challenges by people with common purposes and solidarity in sustained interactions with authorities and elites" (Tarrow, 1994, p. 4) and Diani referred to them as "networks of informal interactions between a plurality of individuals, groups, or associations engaged in a political or cultural conflict on the basis of a shared collective identity" (Diani, 1992, p. 13). Based on these authors we argue that far-right movements might be included in the context of social movements as phenomena of collective action. SMOs are the subunits of the farright movement and provide the basis for the analysis. SMOs have been defined by McCarthy and Zald as "complex or formal organizations, which identify their goals with the preferences of a social movement or a countermovement and attempt to implement those goals" (1977, p. 1218).

\section{HYPERLINK NETWORKS AS A MEANS TO RESEARCH MOBLIZATION STRATEGIES IN CYBERSPACE}

Already in 1977, McCarthy and Zald wrote that "the technologies available for resource accumulation should affect the ability of SMOs within the sector to mobilize resources" (p. 1225). Nowadays, the internet as a comparably new technology that is still evolving offers various different possibilities to mobilize supporters, which include one-sided actions as well as interactions between individual users or groups. As pointed out by Rohr Lopes, the media offers five key aspects for the formation of social movements, which are communication, organization, mobilization, validation and scope enlargement (2014). In addition, the internet takes over a key role for the internationalization of the far-right and is often used for activities and to circumvent national legislation (Bartlett, Birdwell, \& Littler, 2011; Caiani \& Wagemann, 2009; Tateo, 2005). Content that is considered illegal in one country is for example often placed on servers in a different country in order to avoid prosecution. In general, information and communication technologies make it easier for right-wing and populist movements to reach their regular audience (Groschek \& Engelbert, 2012) and additionally enable them to gain the attention of a transnational audience (Caiani \& Kroel, 2014). The internet recently became a "key factor for creating new connections and networks across the globe" for farright movements (Roggeband \& Duyvendak, 2013, p. 101). Activists are seeking 
collaborators across national borders as a response to globalization and the rise of transnational corporations and governing bodies (Van Dyke \& McCammon, 2010). Also, distances between political actors and citizens have been shortened through the new technologies and there is a great potential to use them for political organization and mobilization. Also, the barriers for individual, political participation have been lowered (Groschek \& Engelbert, 2012).

SMOs which belong to various different social movements use new communication technologies to build their online presences, communicate with their followers and each other and share content. In this context, the provision of hyperlinks is a central means that is used to share content and draw attention to like-minded actors or other SMOs. Hence, social networks in various different forms fulfill an important function within the mobilization strategies of social movements (Lim, 2012). Mobilization is defined as "the movement and synchronization of ideas, people or resources for a specific social goal" (Fernandez, 2014, p. 1). It is a collective phenomenon which, amongst others, requires communication and social interaction (Fernandez, 2014), which both happen online as well as offline in the context of today's social movements.

The focus of the research is set to the online interactions, more precisely to hyperlinks that are understood as one particular way of popular mobilization. Roggers and Marres followed a similar approach and used hyperlinks to measure mobilization potential and patterns of alliance building (2000). Hyperlinks might take various different functions (Pilny \& Shumate, 2012) and are in the context of the research understood both a means of alliance and a sign of belonging (Vicari, 2014). Researching hyperlinks gives insights into mobilization strategies of SMOs, as they transport content these SMOs aim to share with their followers and perceive as supporting their goals and ideologies. A hyperlink network is a connective good that provides inter-organizational links via which other actors, ideas or events with similar focuses are brought to the attention of the audience (Shumate \& Lipp, 2008). Except for the case of access-restricted forums or websites exclusion is impossible in the context of hyperlink networks, as hyperlinks are accessible for everybody. Together with the factor of jointness of supply, meaning that one group's benefit from the network does not diminish the benefit of other groups, hyperlink networks are a sort of public good (Pilny \& Shumate, 2012). Two dimensions have been identified as being of particular importance for the mobilization structures and the occurrence of transnationalism within the context of the far-right and populist movement. These are the vertical relations between different territorial levels and the reticular (having the form of a net, or net-like) relations between different social actors (Vicari, 2014, p. 94). Vertical and reticular characteristics are two different levels of information that are contained in a hyperlink. More specifically, as a vertical information the country code top level domains (ccTLD) of the extracted hyperlinks will be analyzed to identify the country, territory or location with which the hyperlink is associated. For the reticular characteristics the types of websites, 
e.g., news portals, social media, services, etc. will be coded. Subsequently vertical and reticular characteristics will be totalized to get a comprehensive overview.

Using the advantages of researching cyberspace as the availability of data and their comparative objectiveness also requires considering the extent to which theories on collective action may be applied to cyberspace. In line with Bennet and Segerberg we claim that "digital media may help to reduce costs in these processes [the spread of collective identification, which includes also mobilization strategies - authors' note] but they do not fundamentally change the action dynamics" (2012, p. 748). As websites are the unit for the analyses, which are maintained and administered by a limited number of administrators and display an organizational coordination of action, the logic of collective action applies. Especially in this case, social technologies and digital media are rather used as a means of mobilization and to manage participation. In other online mobilization contexts, where users directly discuss with each other, technology is increasingly used for spreading personalized interpretations of problems and the selforganization of action, which then leads to other, new action dynamics (Bennet \& Segerberg, 2012, pp. 755-756).

Langenbacher and Schellenberg argue that "transnational processes of exchange and cooperation play an important role in the success of rightwing extremism and right-wing populism in Europe" (2011, p. 22). The cooperation that is taking place within the far-right movement has already been researched in various forms and contexts. Jones, for example, analyzed how relationships between far-right organizations impact nationalist mobilization and party sustainability in Belgium, France, and the United Kingdom (2016). Caiani and Parenti used Social Network Analysis (SNA) to research the potential role of the internet for the Spanish radical right, especially for their national and international contacts, their mobilization and promotion of a collective identity (2011, p. 719). O'Callaghan and his team analyzed the potential of Twitter to act as one possible gateway to communities within the wider online network of the extreme right, using other social media and websites as additional sources (O'Callaghan et al., 2013). Caiani and Wagemann studied the communication networks within the Italian and German extremist right, identifying a quite fragmented network in Italy and a dense and concentrated network in Germany (2009). Avukatu and Lupac concentrated exclusively on Czech far-right online networks and could confirm that the majority of nodes linked to a cluster of central nodes within the network (2014). Doerr used SNA to analyze transnational networks of far-right parties, focusing on the visual and discursive translation of nationalist symbols (2017). Hanzelka and Schmidt compared Czech and German populist far-right movements on Facebook and concluded that German users frequently referred to domestic events and hate comments made were less explicit, while Czech users extensively referred to international incidents and tolerated explicit and violent hate comments from other supporters (2017). 


\section{THE STUDY}

\section{Case selection: Countries and movements}

The research is based on case studies from two countries, namely the Czech Republic and Germany, and three selected SMOs for each country that represent different segments of the far-right and populist movement in both countries. A case study is defined as an "in-depth study of a single unit" with the "aim to elucidate features of a larger class of similar phenomena" (Gerring, 2004, p. 341). Using fundamentally different cases is an often-used method to select case studies for research (Gerring, 2004). The selected countries represent very different situations; Germany, a high-income Western democracy, has a diversified far-right scene which is quite influential in Europe. The Czech Republic on the other hand is a post-communist, post-transitional regime and the far-right is quite differentiated; though, it is not as influential in the European context as the German one. The research is based on a multiple case study as defined by Yin (2014), expecting contrasting results correlated to the nationality of the SMOs and the segment of the far-right they belong to.

The selection of German and Czech far-right and populist SMOs is based on the above provided definitions of the far-right and populism; the selected SMOs belong to different segments of the diversified far-right movement in both countries, some being stronger populists than others. The selection aims to give an insight into the far-right movement but does not necessarily cover all its facets. Also, the selected Czech and German movements belong to the same segments respectively, however, the article does not focus on their comparison. Instead, an overview on the far-right movement as a whole should be provided, which means taking its various different segments as well as populist and non-populist actors into account. The following SMOs have been selected for the analyses:

- Identitarian movement; Czech (IMCZ) and German (IBDE) branches. The Identitarian movement is a youth subculture and has recently been very popular; the movement focuses on the idea of a planned exchange of populations and about the imminent loss of European culture, perceiving different cultures as being not compatible with each other and therefore strictly rejecting multiculturalism (Ge-nerace Identity, 2018; Identitäre Bewegung, 2018). Basically, these ideas belong to the ideology of ethnopluralism. Populist characteristics are hardly found in the context of these movements, they rather represent closed groups than addressing a broader audience.

- Delnicka Mladez (DM, Eng.: Workers youth) from the Czech Republic and Junge Nationalisten (JN, Eng.: Young nationalists) from Germany. These movements represent the youth groups of the right-wing parties Worker's Party of Social Justice (Dělnická Strana Socialní Spravedlností, DSSS) and National Democratic Party of Germany (Nationaldemokratische Partei Deutschlands, NPD). Both are adopting the strategies of the mentioned parties and their respective narratives 
about an ethnically pure nation and protection of the homeland. Also, both movements partly display tendencies of neo-Nazism (Delnicka Mladez, 2018; Junge Nationalisten, 2018). To a certain extent they exhibit populist characteristics, e.g., by opposing their governments, by their strong emphasis on the nation and identity of the people and by their claim to be the only actor representing the people.

- Islam v Ceske Republice Nechceme, (IVCRN, Eng.: We do not want Islam in the Czech Republic) from the Czech Republic and Pegida (PEG, German shortcut for "Patriotic Europeans Against the Islamization of the Occident") from Germany. These are anti-immigration/anti-Islam movements, which are referring to an imminent Islamization of the occident. Pegida has for a very long time been emphasizing its democratic nature and gained a lot of support in a very short time in Germany at the end of 2014; IVCRN can be seen as its imitator in many aspects (Pegida, 2018; IVCRN, 2018). Both movements clearly make use of populist strategies, visible for example in the direct claim by Pegida that the government or the leaders of the country are corrupt, their slogan "we are the people" and their strong opposition against the government.

\section{Research aim and methods}

The research aims to analyze the mobilization strategies of Czech and German farright and populist movements in cyberspace. As described above, the new possibilities provided via the internet are crucial for the mobilization strategies of social movements and the far-right in general. Also, the content hyperlinked by far-right SMOs is an important part of their mobilization strategies. Based on this, the focus of the analysis was set to online interactions, more precisely the provision of hyperlinks as a direct reference to a different page and an interaction with the users of a page. The research aim is to explore the content hyperlinked by the selected farright movements from the Czech Republic and Germany, focused on transnational, vertical relations and reticular relations to various different social actors. The explorative research is based on the following research questions:

Q1: Which are the vertical characteristics of websites hyperlinked by the selected Czech and German SMOs?

Q2: Which are the reticular characteristics of websites hyperlinked by the selected Czech and German SMOs?

The websites hyperlinked by the Czech and German SMOs will be extracted and analyzed to get a deeper insight into their mobilization strategies. To answer the first research question referring to vertical characteristics, the nationality of hyperlinked pages as provided in ccTLD will be coded. For the second research question referring to reticular relations, the type of content that is hyperlinked will be analyzed. 
The web crawl for the analyses has been done by using the web crawler VOSON (Virtual Observatory for the Study of Online Networks, Ackland, 2010). VOSON is a web application that enables the user to crawl the web, starting from so-called seed pages, which the users define according to their research interest. Subsequently it is possible to carry out basic graphic analyses of the crawled data and calculate basic SNA data. The main web pages of the above-introduced Czech and German far-right SMOs were used as seed sites. In the graphic depiction, websites are depicted as nodes, while hyperlinks are depicted as ties. The option of grouping subpages of a website and depicting them as one node was used to ensure clarity and readability. Hyperlinking to the same page group, even if not referring to exactly the same subpage, points to a similar orientation and/or motivation and allows concluding for similar mobilization strategies. Based on the extracted data, a complete network was drawn, which depicts all the crawled sites grouped into main pages, their direct connections and commonalities, as well as separately hyperlinked page groups.

\section{Hyperlink network of selected Czech and German SMOs}

For a first overview, a graphic depiction of the seed pages and the hyperlinked pages groups was generated from the crawled data, which is shown in Figure 1. The figure displays both the individually hyperlinked content (individual clusters) and content which is hyperlinked by two or more of the selected SMOs (connecting page groups). Also, the figure shows the differing sizes of the individual clusters; while, e.g., Pegida does not hyperlink to many other pages both the Czech and the German branches of the Identitarian movement provide a vast amount of hyperlinks to other pages.

Figure 1 provides an overview on the connecting page groups which are hyperlinked by two or more seed pages. The most central page group is Facebook, to which all of the seed pages hyperlink with an inbound link. Overall, the network shows that all of the selected seed SMOs rather focus on their own clusters and that hyperlinks to varying amounts of connecting page groups and directly to other selected SMOs are less frequent. In relation to mobilization strategies this might be interpreted as the movements each concentrating on their own key audience but still having direct overlaps with other movements. Mainly between the different branches of the Identitarian movements and between the IMCZ and IVCRN there are a lot of indirect connections via connecting page groups. Additionally, these movements are directly connected to each other via hyperlinks, which point to similar audiences and mobilization strategies. Also, the movement IVCRN links to a comparably high amount of connecting page groups, but there is only one connection to a different seed. Finally, PEG, JN and DM are linking to low amounts of connecting third page groups and also have comparably small individual clusters. 


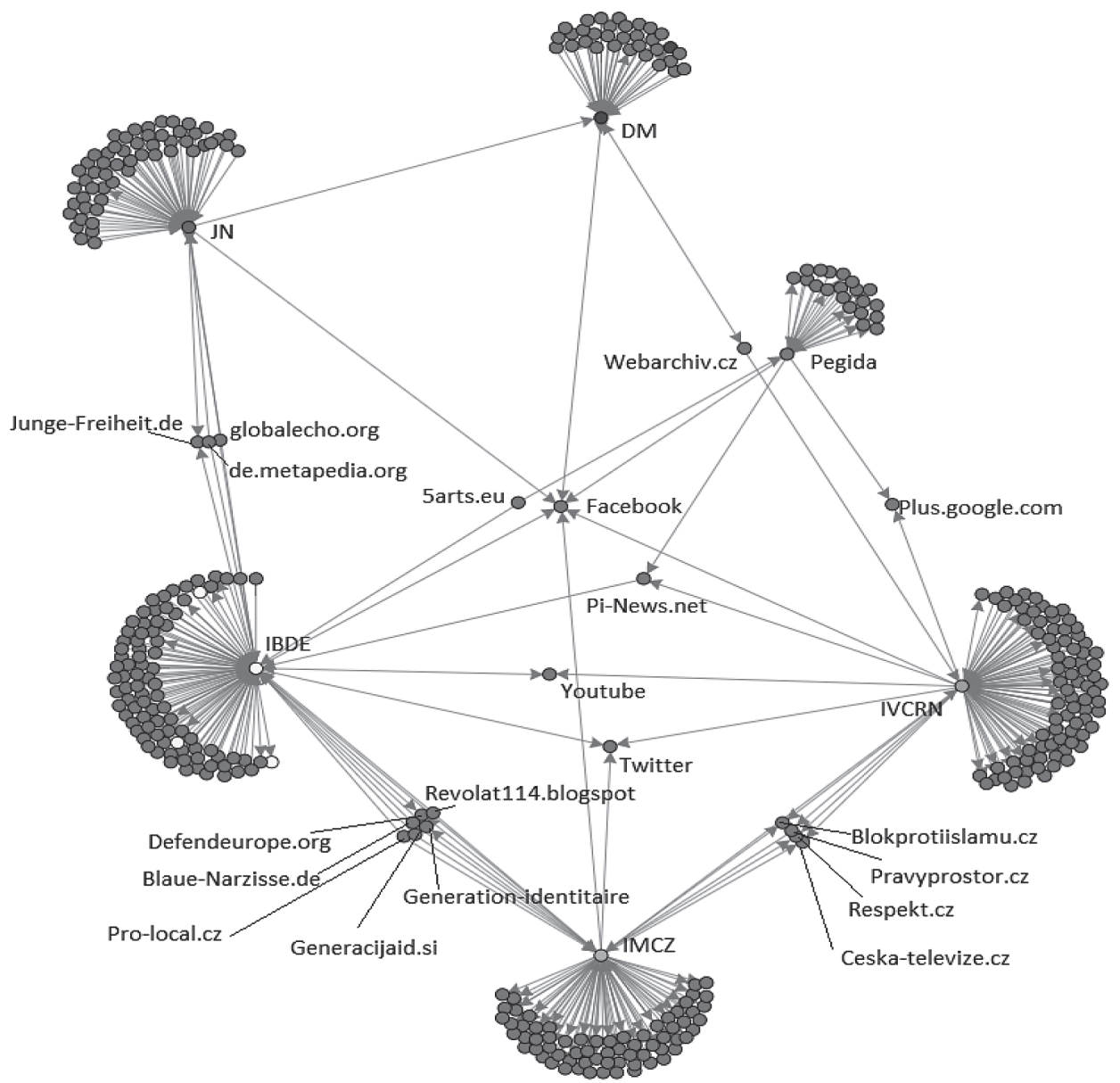

Figure 1. Oriented hyperlink network; nodes: page groups, ties: hyperlinks

Source: Authors.

PEG is not linked to any other seeds, while DM is connected with one and JN even with two other seeds.

A first look at the hyperlink network revealed no systematic difference between populist and non-populist far-right movements. While IVCRN has a relatively big individual cluster and many hyperlinks to connecting page groups, PEG, which is one of the most populist SMOs in the context of the research has a very small individual cluster. However, this could also be caused by other factors, e.g., primary usage of other channels for mobilization and communication. Table 1 provides an overview on the in- and outbound links to connecting page groups that could be identified in the network. 
Hyperlink networks as a means of mobilization used by far-right movements

Table 1. Overview on the common content within the network and the respective seed pages that hyperlink to these

\begin{tabular}{|l|c|c|c|c|c|c|}
\hline \multicolumn{1}{|c|}{ Connectors } & IBDE & IMCZ & PEG & IVCRN & JN & DM \\
\hline Facebook.com & I & I & I & I & I & I \\
\hline Twitter.com & I & I & & I & & \\
\hline pi.news.net & O & & I & I & & \\
\hline 5arts.eu & O & & O & & & \\
\hline generacijaid.si & O & O & & & & \\
\hline revolta114.blogspot.com & O & O & & & & \\
\hline defend-europe.org & I & I & & & & \\
\hline generation-identitaire.com & O & I & & & & \\
\hline pro-local.cz & O & O & & & & \\
\hline blauenarzisse.de & O & O & & & & \\
\hline jungefreiheit.de & I & & & & I & \\
\hline de.metapedia.org & O & & & & O & \\
\hline globalecho.org & O & & & & O & \\
\hline youtube.com & I & & & I & & \\
\hline plus.google.com & & & I & I & & \\
\hline blokprotiislamu.cz & & I & I & & & \\
\hline pravyprostor.cz & & O & & I & & \\
\hline respekt.cz & & I & & I & & \\
\hline ceskatelevize.cz & & $\mathbf{1 4}$ & $\mathbf{5}$ & $\mathbf{9}$ & $\mathbf{4}$ & $\mathbf{3}$ \\
\hline webarchiv.cz & & & I & & \\
\hline TOTAL & & & & \\
\hline
\end{tabular}

I - Inbound link from the seed, $\mathrm{O}$ - Outbound link to the seed.

Source: Authors.

\section{Clusters of individual SMOs}

Besides the content hyperlinked by several seeds coincidently and the mutual connections between the seed webpages also the individual clusters of the selected SMOs were analyzed. For the first research question, which refers to vertical relations, the ccTLD of the hyperlinked page groups was coded and analyzed for each SMO separately. The results were summed up in four categories, which were "DE" and "CZ" to refer to the countries of origin of the selected SMOs. Additionally there was "Intl" as code for websites that were not associated with any country and "Others" for all other nationalities. The results of this analysis are displayed in Figure 2. 


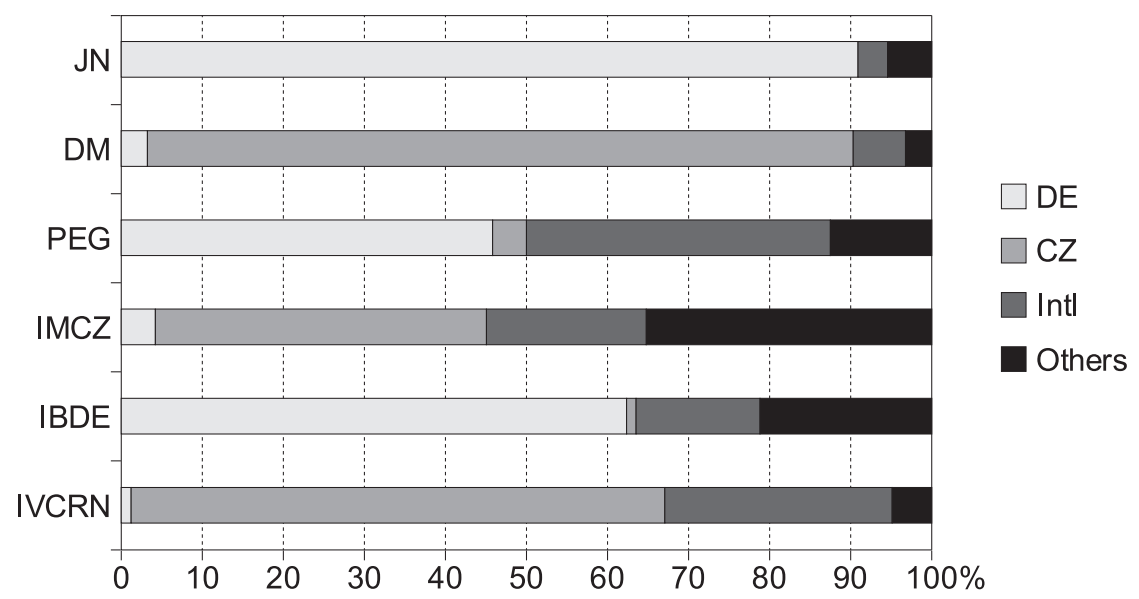

Figure 2. Coded, summarized ccTLD (vertical relations) for each SMO in percent

Source: Authors.

The amount of page groups hyperlinked by the SMOs differed. The smallest cluster was that belonging to Pegida, followed by DM. IBDE hyperlinked to most other page groups. All SMOs provided most of the hyperlinks to domestic content, which means that they focus on their countries of origin in the context of their mobilization strategies. IMCZ, IBDE and IVCRN frequently hyperlinked to international content (category "Intl") and the greatest diversity of other nationalities (category "Others") was found for the two Identitarian movement websites.

For the second research question related to reticular relations the types of pages the SMOs were hyperlinking to was analyzed and the results summed up. The results of this analysis can be found in Figure 3. The used codes have been developed during the process of analysis based on an open coding procedure (Kohlbacher, 2006); while most categories are clear and exclusive the differentiation of right-wing propaganda and news portal includes a gray area. However, this concerns only a few pages and thus does not influence the results significantly. All SMOs hyperlinked to different kinds of news portals; the highest amounts of hyperlinks to news portals could be found for IMCZ, IBDE and IVCRN, which might be interpreted as these movements integrating a lot of information into their mobilization strategies. Further, these three SMOs and JN provided a lot of hyperlinks to other movements, which in many cases were their sub-organizations, projects they started or branches from other locations. Thus, they seem to network and cooperate a lot with likeminded actors and generally be very active. Mostly DM and JN frequently linked to parties, as expected to DSSS and NPD respectively. All analyzed SMOs also provided links to different kinds of services (e.g., web shops, propaganda materials, web designs) or to encyclopedias. As a surprise came the hyperlinks to Christian but also to Jewish and Islamic pages, which were provided mostly by IBDE and IVCRN. The interpretation of these pages in the context of the mobilization strategies remains unclear. 


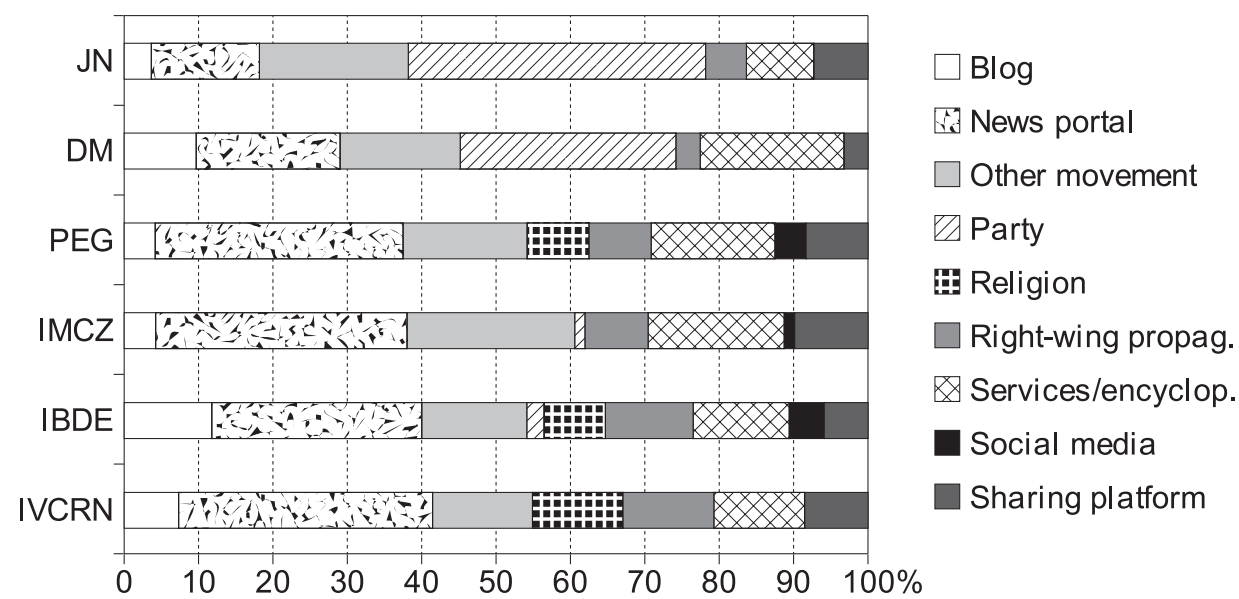

Figure 3. Coded, summarized actors (reticular relations) hyperlinked by each SMO in percent

Source: Authors.

\section{DISCUSSION}

In order to analyze the mobilization strategies employed by far-right and populist movements in the Czech Republic and Germany, the content to which the selected far-right movements hyperlink has been analyzed. The ccTLDs of the hyperlinked pages have been coded to learn more about the vertical relations to other countries and the types of the hyperlinked content were coded to take a closer look to the reticular relations among different actors.

With respect to the vertical connections, all of the movements have been found to hyperlink more to domestic content than to international, with the party youth groups linking nearly exclusively to domestic pages, Pegida linking a lot to international content but to a small number of pages in total and the Identitarian movement from the Czech Republic linking to a number of websites from various different countries. This allows conclusions to be arrived at regarding the extent to which the single movements focus to their countries of origin in their mobilization strategies and how intense they also include international pages or pages from other countries into their mobilization strategies. The vertical mobilization strategies seem to be neither correlated to the country, nor to the use of populist strategies. The only correlation that could be established was a weak link to the segment of the far-right movement.

As for the reticular characteristics of the hyperlinked content, various different news portals were the most important type of content both for the anti-Muslim segment and for the Identitarian movements, which strongly or at least to a certain extent make use of populist strategies. This means that the provision and spreading of information is a key part of their mobilization strategies. As expected, the party youth groups extensively linked to the parties they are connected with. Reticular 
mobilization strategies therefore seem to be rather connected with the segment of the far-right movement as an organization than with the country of origin of a movement.

The research itself provides a first insight into the mobilization strategies of the selected movements rather than universal or absolute results. In some cases third variables, for example the usage of other communication channels for mobilization, could not be excluded. Additionally, it is a rather small study that includes only a few case studies representing the different segments in the two selected countries. Future research could include more far-right SMOs either from different segments or more representatives of the single segments to verify the results based on a larger case study. Also, the results could be verified by including other countries and research on structural differences between them and the ideologies behind the mobilization strategies and their connections e.g., with the success that a given movement achieves could be closer analyzed by a qualitative approach.

\section{CONCLUSION}

The selected SMOs strongly concentrate on their countries of origin in their mobilization strategies, which was most significant for the party youth groups JN and DM. The analyzed branches of the Identitarian movement, on the other hand, linked to a number of page groups from other countries and also Pegida included international content in its mobilization strategy.

With respect to the reticular, net-like relations to other actors the types of hyperlinked websites were coded and summarized. The two branches of the Identitarian movement and IVCRN hyperlinked to high amounts of news portals, which means that the provision and spreading of information is an important part of their mobilization strategies. Also, these three SMOs and JN frequently provided hyperlinks to other movements, which means that interaction with likeminded actors is another important part of their mobilization strategy.

\section{ACKNOWLEDGMENTS}

This article was written at Masaryk University with the support of the Specific University Research Grant provided by the Ministry of Education, Youth and Sports of the Czech Republic.

\section{REFERENCES}

Ackland, R. (2010). Www hyperlink networks. In D. Hansen, B. Schneiderman, \& M. Smith (Eds.), Analyzing social media networks with NodeXL: Insights from a connected world (pp. 181-201). Canberra: Morgan-Kaufmann. 
Aisch, G., Pearce, A., \& Rousseau, B. (2017). How far is Europe swinging to the right? New York Times. Retrieved December 10, 2018, from https://www.nytimes.com/interactive/2016/05/22/world/europe/europe-right-wing-austria-hungary.html.

Avukatu, J., \& Lupac, P. (2014). Analýza on-line sítě české krajní pravice. Rexter, 12(1), 41-74.

Backes, U., \& Jesse, E. (1993). Politischer Extremismus in der Bundesrepublik Deutschland. Berlin: Propyläen.

Bartlett, J., Birdwell, J., \& Littler, M. (2011). “The rise of populism in Europe can be traced through online behaviour..." The new face of digital populism. London: Demos. Retrieved December 10, 2018, from https://www.demos.co.uk/files/Demos_OSIPOP_Book-web_03.pdf?1320601634.

Bennett, L., \& Segerberg, A. (2012). The logic of connective action. Information, Communication \& Society, 15(5), 739-768.

Bötticher, A., \& Mares, M. (2012). Extremismus: Theorien, Konzepte, Formen. München: Oldenbourg Verlag.

Bundeswahlleiter (2017). Bundestagswahl 2017 Ergebnisse; Der Bundeswahlleiter. Retrieved December 10, 2018, from https://www.bundeswahlleiter.de/bundestagswahlen/2017/ergebnisse.html.

Caiani, M., \& Kroel, P. (2014). The transnationalization of the extreme right and the use of the internet. International Journal of Comparative and Applied Criminal Justice, 39(4), 331-351.

Caiani, M., \& Parenti, L. (2011). The Spanish extreme right and the internet. Análise Social, 46(201), 719-740.

Caiani, M., \& Wagemann, C. (2009). Online networks of the Italian and German extreme right. Information, Communication \& Society, 12(1), 66-109.

DELNICKA MLADEZ (Workers' youth) (2018). Website of the Czech far-right party youth. Retrieved December 10, 2018, from http://www.delnickamladez.cz/.

Diani, M. (1992). The concept of social movement. Sociological Review, 40, 1-25.

Doerr, N. (2017). Bridging language barriers, bonding against immigrants: A visual case study of a transnational network public created by far-right activists in Europe. Discourse and Society, 28(1), $3-23$.

Fernandez, L. (2014). An analysis of the global mobilization hyperlink network for vulnerable islands. Dissertation at Michigan State University, Michigan.

GENERACE IDENTITY (2018). Website of the Identitarian movement of the Czech Republic. Retrieved December 10, 2018, from http://generace-identity.cz/.

Gerring, J. (2004). What is a case study and what is it good for? The American Political Science Review, 98(2), 341-354.

Gomez-Reino, M. (2018). Nationalisms in the European arena: Trajectories of transnational party coordination. Cham: Palgrave Macmillan.

Greven, T. (2016). The rise of right-wing populism in Europe and the United States: A comparative perspective. Berlin: Friedrich Ebert Stiftung.

Groschek, J., \& Engelbert, J. (2012). Double differentiation in a cross-national comparison of populist political movements and online media uses in the United States and the Netherlands. New Media \& Society, 15(2), 183-212.

Hanzelka, J., \& Schmidt, I. (2017). Dynamics of cyberhate in space of social media: A comparative analysis of anti-Muslim movements in the Czech Republic and Germany. International Journal of Cyber Criminology, 11(1), 143-160.

Holtmann, E., Krappidel, A., \& Rehse S. (2006). Die Droge Populismus - zur Kritik des politischen Vorurteils. Wiesbaden: VS Verlag.

IDENTITÄRE BEWEGUNG (2018). Website of the Identitarian movement Germany. Retrieved December 10, 2018, from https://www.identitaere-bewegung.de/.

IVCRN (Islam v Ceske Republice Nechceme - We do not want Islam in the Czech Republic) (2018). Website of the Czech anti-Islam movement. Retrieved December 10, 2018, from https://www. ivcrn.cz/. 
Jones, S. (2016). Mapping extremism: The network politics of the far-right. Dissertation at Georgia State University. Retrieved December 10, 2018, from http://scholarworks.gsu.edu/political_science_diss/42.

JUNGE NATIONALISTEN (Young nationalists) (2019). Website of the German far-right party youth. Retrieved December 10, 2018, from http://aktion-widerstand.de.

Klandermans, B. (2013). The dynamics of demand. In J. Van Stekelenburg, C. Roggeband, \& B. Klandermans (Eds.), The future of social movement research (pp. 3-16). Minneapolis: University of Minnesota Press.

Kohlbacher, F. (2006). The use of content analysis in qualitative content analysis in case study research. Forum Qualitative Social Research. Retrieved November 27, 2018, from http://www.qualitativeresearch.net/index.php/fqs/article/view/75/153.

Köhler, D. (2015). The radical online: Individual radicalization processes and the role of the internet. Journal for De-Radicalization, Winter 2015/14(1), 116-134. Retrieved December 10, 2018 from http://journals.sfu.ca/jd/index.php/jd/article/view/8.

Kopeček, L. (2007). The far right in Europe: A summary of attempts to define the concept, analyze its identity, and compare the Western European and Central European far right. Středoevropské politické studie, 9(4), 280-293.

Langenbacher, N., \& Schellenberg, B. (2011). Is Europe on the "right" path? Right-wing extremism and right-wing populism in Europe. Berlin: Friedrich Ebert Stiftung, Forum Berlin. Retrieved December 10, 2018, from http://library.fes.de/pdf-files/do/08338.pdf.

Lim, M. (2012). Clicks, cabs, and coffee houses: Social media and oppositional movements in Egypt, 2004-2011. Journal of Communication, 62(2), 231-248.

McCarthy, J. D., \& Zald, M. N. (1977). Resource mobilization and social movements: A partial theory. The American Journal of Sociology, 82(6), 1212-1241.

Mudde, C. (2014). The far-right and the European elections. Current History, 113(761), 98-103.

Mudde, C. (2015, February 17). The problem with populism. The Guardian. Retrieved December 10, 2018, from https://www.theguardian.com/commentisfree/2015/feb/17/problem-populism-syriza -podemos-dark-side-europe.

Müller, J.-W. (2016, May 6). Populisten - woran man sie erkennen kann. Frankfurter Allgemeine Zeitung. Retrieved December 10, 2018, from https://www.google.de/amp/m.faz.net/aktuell/feuilleton/debatten/populisten-woran-man-sie-erkennen-kann-14217268.amp.html.

O'Callaghan, D., Greene, D., Conway, M., Carthy, J., \& Cunningham, P. (2013). Uncovering the wider structure of extreme right communities spanning popular networks. Ithaca, New York: Cornell University Library. Retrieved December 10, 2018, from https://arxiv.org/abs/1302.1726.

PEGIDA (Patriotische Europäer gegen die Islamisierung des Abendlandes; Patriotic Europeans against the Islamization of the Occident) (2019). Website of the German anti-Islam movement. Retrieved December 10, 2018, from http://www.pegida.de/.

Pilny, A., \& Shumate, M. (2012). Hyperlinks as extensions of offline instrumental collective action in information. Communication \& Society, 15(2), 260-286.

Polletta, F., Chen, P. B. C., Gardner, B. G., \& Motes, A., (2013). Is the internet creating new reasons to protest? In J. Van Stekelenburg, C. Roggeband, \& B. Klandermans (Eds.), The future of social movement research (pp. 17-36). Minneapolis: University of Minnesota Press.

Rogers, R., \& Marres, N. (2000). Landscaping climate change: A mapping technique for understanding science and technology debates on the World Wide Web. Public Understanding of Science, 9(2), $1-23$.

Roggeband, C., \& Duyvendak, J. W. (2013). The changing supply side of mobilization: Questions for discussion. In J. Van Stekelenburg, C. Roggeband, \& B. Klandermans (Eds.), The future of social movement research (pp. 95-106). Minneapolis: University of Minnesota Press. 
Rohr Lopes, A. (2014). The impact of social media on social movements: The new opportunity and mobilizing structure. Creighton University. Retrieved December 10, 2018, from https://www.creighton.edu/fileadmin/user/CCAS/departments/PoliticalScience/Journal_of_Political_Research_ JPR_/2014_JSP_papers/Lopes_JPR.pdf.

Shumate, M., \& Lipp, J. (2008). Connective collective action online: An examination of the hyperlink network structure of an NGO issue network. Journal of Computer-Mediated Communication, 14(1), 178-201.

Tarrow, S. (1994). Power in movement. Cambridge: Cambridge University Press.

Tateo, L. (2005). The Italian extreme right on-line network: An exploratory study using an integrated social network analysis and a content analysis approach. Journal of Computer-Mediated Communication, 10(1). Retrieved December 10, 2018, from http://onlinelibrary.wiley.com/ doi/10.1111/j.1083-6101.2005.tb00247.x/full.

Van Dyke, N., \& McCammon, H. J. (2010). Strategic alliances: Coalition building and social movements. Minneapolis: University of Minnesota Press.

Vicari, S. (2014). Networks of contention: The shape of online transnationalism in early twenty-first century social movement coalitions. Social Movement Studies, 13(1), 92-109.

Yin, R. K. (2014). Case study research design and methods. Thousand Oaks, CA: Sage. 